\title{
ANALISIS KUALITAS PRODUK DRUM DAN METAL PACKAGING (STUDI KASUS: PLANT 1 PT GUNA SENAPUTRA SEJAHTERA)
}

\author{
Bintang Bagaskara K., Clara Puspita N., Stephen Alexander, Lithrone Laricha S. \\ Program Studi Teknik Industri Jurusan Teknologi Industri \\ Fakultas Teknik Universitas Tarumanagara \\ e-mail: bintangkorda@yahoo.co.id
}

\begin{abstract}
ABSTRAK
PT Guna Senaputra Sejahtera adalah salah satu perusahaan produsen yang memproduksi metal parts, jig, dan dies. Penelitian ini berfokus kepada perbaikan beberapa produk metal parts di perusahaan tersebut yakni lock assy hood, link assy acc, hook engine, bumper dan pipe tilt. Produk-produk tersebut memiliki kendala penanganan kualitas terbanyak diantara 656 produk lainnya sehingga membuat customer complaint yang cukup menganggu pihak perusahaan, sehingga dengan penelitian ini diharapkan dapat memperbaiki kualitas produk dan menurunkan angka cacat produk dengan Metode Seven Quality Tools (fishbone, pareto diagram, histogram, dan pie chart) dan analisa 4M1E (Man, Method, Material, Machine, Environment). Diharapkan dengan melakukan penelitian ini dapat memberikan solusi dan metode baru baik untuk departemen proses produksi dan departemen quality control dan juga pihak manajemen perusahaan dalam menerapkan zero defect untuk setiap produk. Hasil penelitian juga memuat tentang mayoritas kecacatan produk yaitu burry, dirty, scratch, dan finger mark. yang merugikan cost, waktu, dan efisiensi proses. Hal ini diakibatkan belum terlaksananya SOP, kurangnya mesin-mesin terotomasi dan kurangnya maintenance mesin. Sehingga harus diterapkan sosialisasi, training dan sanksi untuk SOP, preventive maintenance mesin, pembuatan ruangan khusus dan pendingin ruangan untuk meningkatkan kenyamanan operator sehingga produktivitas bekerja dapat bertambah.
\end{abstract}

Kata kunci: Kualitas, Seven Tools, Analisa 4M1E.

\begin{abstract}
Guna Senaputra Sejahtera, Ltd. is one of the biggest producer of metal parts, jig, and dies. This research foucus on continous improvement of metal parts in that factory such as lock assy hood, link assy acc, hook engine, bumper, and pipe tilt. Those products have the biggest problem in quality beside other 656 products so it makes customer's complaints which bother the company, The researcher wish by doing this research, the reasearcher can improve the quality of the products and determine the number of defects with Seven Quality Tools (fishbone, pareto diagram, histogram, and pie chart) and 4MIE analysis (Man, Method, Material, Machine, Environment). By doing this research, the researcher can give solutions and new method for production process department as well as quality control department and management otority in implementation of zero defect for every products. The result contains of the most defect type which is burry, dirty, scratch, and finger mark, those inflict the financial loss, time, and process eficiency. This inflict caused by not doing SOP, less of otomation machines, and less of machines's maintenences. Therefore should be done a socialization, training, and sanctions for the SOP, machines preventive maintenence, construct special room for increase ergonomic in operator of the machines so that also increase productivity of works.
\end{abstract}

Keywords: Quality, Seven Tools, 4MIE Analysis.

\section{PENDAHULUAN}

PT Guna Senaputra Sejahtera merupakan industri manufaktur pembuatan drum dan metal packaging yang berlokasi di Jl. Pangkalan III Km 2,4 Kedung Halang Talang, Bogor 16710. Oleh karena itu pengendalian kualitas dalam produksi harus sangat diperhatikan dikarenakan jenis permintaan yang selalu bervariasi dengan standar yang berbeda-beda bergantung permintaan dari konsumen.

Berdasarkan latar belakang ini, penulis akan melakukan analisa terhadap sistem pengendalian kualitas dari proses produksi PT Guna Senaputra Sejahtera di mana dilakukan analisa pada divisi part ini dikarenakan memiliki tingkat kesalahan yang paling 
banyak dibandingkan produk lainnya. Pembahasan sendiri akan dijabarkan baik dalam bahasan umum dan bahasan khusus yang memperlihatkan penyebab-penyebab terjadinya permasalahan dengan menggunakan metode Why Analysis, analisa dari data yang telah dikumpulkan, dan memberikan solusi penanganan serta saran yang dapat berguna dalam mengurangi tingkat permasalahan yang terjadi. Pada penelitian ini, digunakan 2 jenis metode yaitu metode 4M1E Why Analysis dan Metode Seven Quality Tools. Penelitian sebelumnya Metode Seven Tools digunakan dalam analisis Pengendalian Kualitas Produk Kayu [1].

\section{TINJAUAN PUSTAKA}

Menurut Ahyari, pengendalian kualitas merupakan suatu aktivitas (manajemen perusahaan) untuk menjaga dan mengarahkan agar kualitas produk atau jasa perusahaan dapat dipertahankan sebagaimana yang telah direncanakan [2].

Metode 4M1E adalah merupakan metode analisa dari penjaminan mutu yang melihat faktor manusia, mesin, material, metode, dan lingkungan yang dapat menggambarkan sebab-akibat dari masalah kualitas tersebut. Sedangkan Metode Seven Quality Tools adalah alat dasar yang digunakan untuk memecahkan permasalahan yang dihadapi oleh produksi, terutama pada permasalahan yang berkaitan dengan kualitas (mutu) [3-9].

\section{METODOLOGI PENELITIAN}

Pada Gambar 1 dapat dilihat tahapan-tahapan yang dilakukan dalam melakukan penelitian ini.

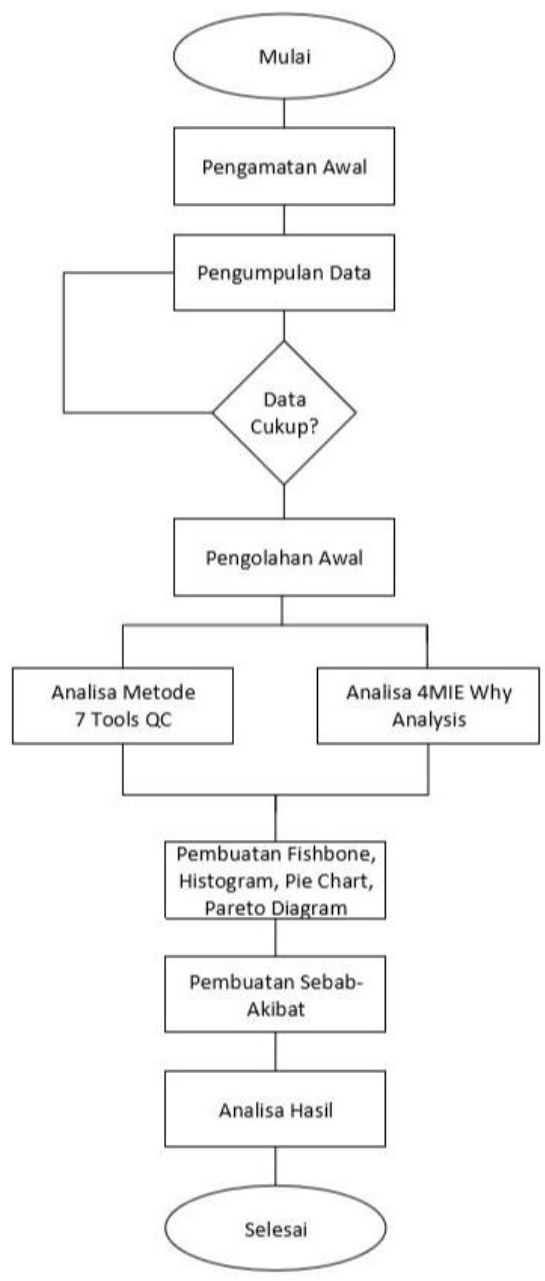

Gambar 1. Tahapan Penelitian 


\section{HASIL DAN PEMBAHASAN}

Dari 661 jenis produk PT GSS, diambil 5 jenis produk yang paling banyak memiliki jumlah cacat dari produk-produk lain dapat dilihat pada Tabel 1 yaitu produk Lock Assy Hood, Link Assy Acc, Hook Engine, Bumper, dan Pipe Tilt dan dari kelima produk tersebut produk Lock Assy Hood memiliki jumlah cacat terbesar dengan jumlah presentasi cacat $6 \%$ dari total jumlah produksi yang dihasilkan seperti ditunjukkan pada Gambar 2.

Tabel 1. Jumlah Cacat

\begin{tabular}{lccccc}
\hline \multicolumn{1}{c}{ Produk } & $\begin{array}{c}\text { Jumlah } \\
\text { Produksi (pcs) }\end{array}$ & $\begin{array}{c}\text { Jumlah Cacat } \\
\text { (pcs) }\end{array}$ & $\begin{array}{c}\text { Cacat dalam } \\
\text { Jumlah Produksi }\end{array}$ & $\begin{array}{c}\text { \% } \\
\text { Akumlatif }\end{array}$ & $\begin{array}{c}\text { \% Cacat } \\
\text { Proporsi }\end{array}$ \\
\hline Lock Assy Hood & 18233 & 1094 & $1094 / 18233$ & 83 & 6 \\
Link Assy Acc & 15380 & 759 & $759 / 15380$ & 88 & 5 \\
Hook Engine & 17180 & 859 & $859 / 17180$ & 93 & 5 \\
Bumper & 15425 & 617 & $617 / 15425$ & 97 & 4 \\
Pipe Tilt & 16400 & 492 & $492 / 16400$ & 100 & 3 \\
\hline
\end{tabular}

\section{PIE CHART JUMLAH CACAT PLANT 1}

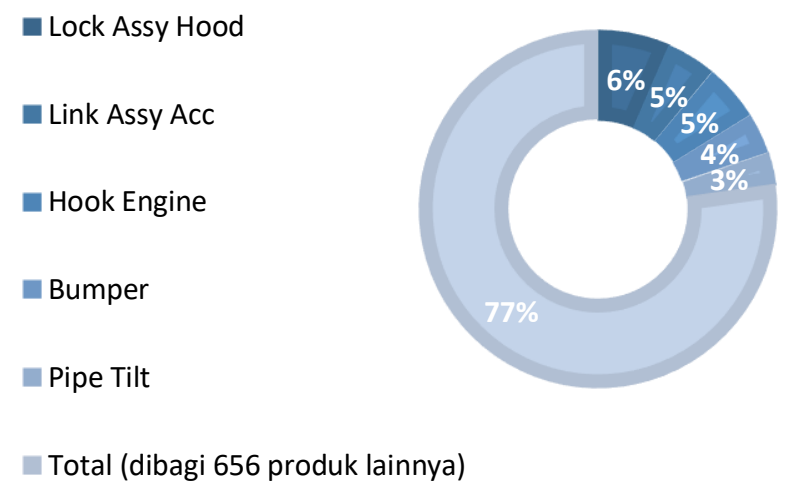

Gambar 2. Pie Chart Jumlah Cacat Plant 1

Hasil Perhitungan untuk masing-masing produk berdasarkan jenis cacat burry, scratch, missing bending, dirty, bubble, finger mark, through cut, over hole dan peel off dianalisa menggunakan Diagram Pareto. Hasil perhitungan dapat dilihat pada Gambar 3 untuk produk Hook Engine, Gambar 4 untuk produk Assy Hood, Gambar 5 untuk produk Assy Tilt, Gambar 6 untuk produk Assy Acc, dan Gambar 7 untuk produk Bumper OKO50, dan hasil rekapan jenis cacat untuk seluruh produk dapat dilihat pada Tabel 2.

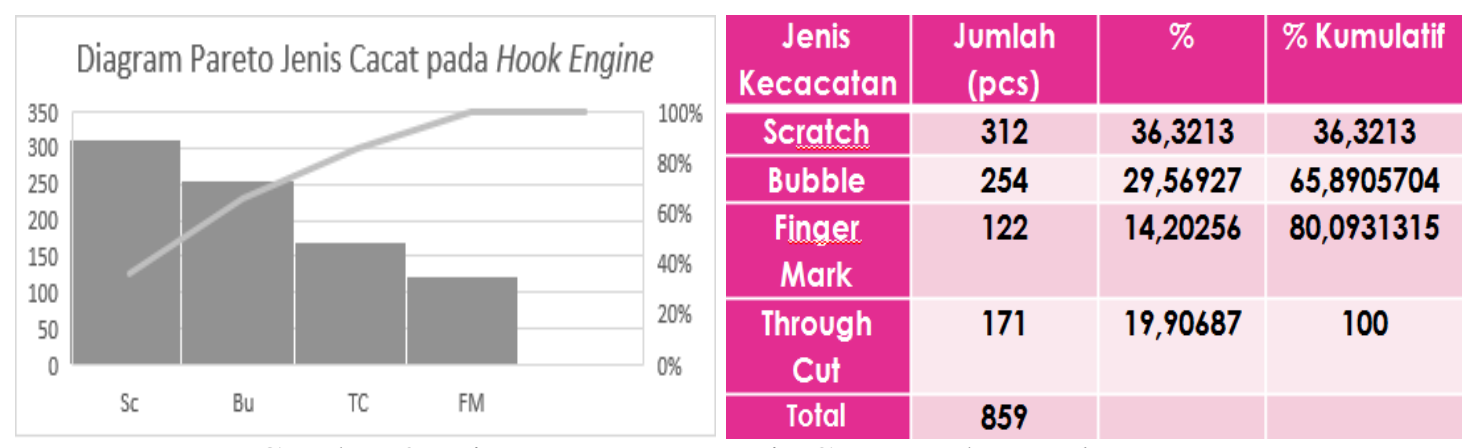

Gambar 3. Diagram Pareto Jenis Cacat pada Hook Engine 
Analisis Kualitas Produk Drum dan Metal Packaging (Studi Kasus: Plant 1 PT Guna Senaputra Sejahtera) Bintang Bagaskara K., Clara Puspita N., Stephen Alexander, Lithrone Laricha S.

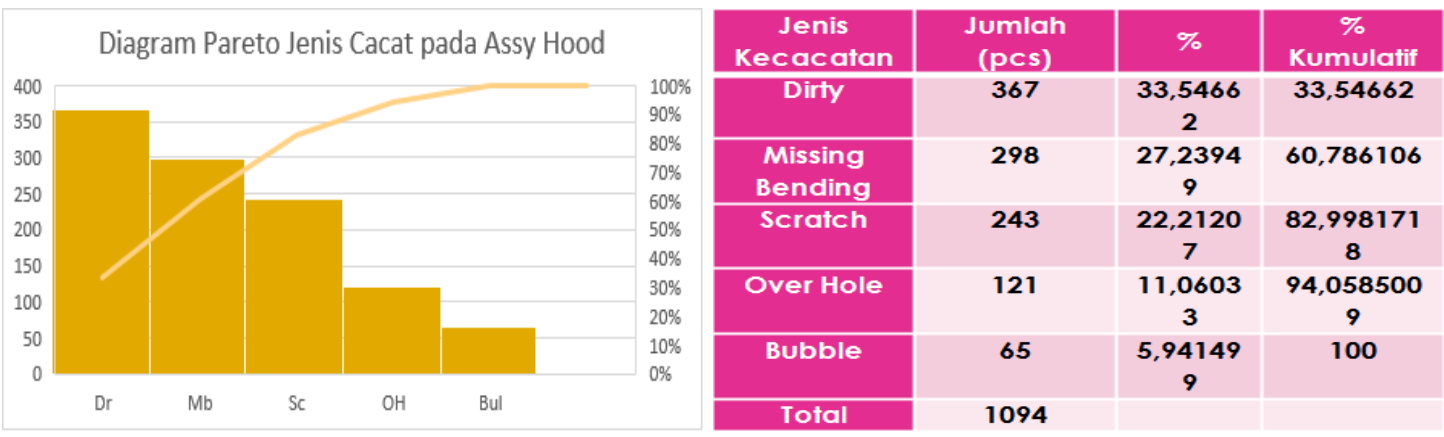

Gambar 4. Diagram Pareto Jenis Cacat pada Assy Hood

\begin{tabular}{|c|c|c|c|}
$\begin{array}{c}\text { Jenis } \\
\text { Kecacatan }\end{array}$ & $\begin{array}{c}\text { Jumlah } \\
\text { (pcs) }\end{array}$ & $\%$ & $\begin{array}{c}\% \\
\text { Kumulatif }\end{array}$ \\
\hline $\begin{array}{c}\text { Bubble } \\
\text { Missing } \\
\text { Bending }\end{array}$ & 233 & 47,35772 & 47,35772 \\
\hline $\begin{array}{c}\text { Through } \\
\text { Cut }\end{array}$ & 13 & 2,642276 & 93,495935 \\
\hline $\begin{array}{c}\text { Finger } \\
\text { Mark }\end{array}$ & 32 & 6,504065 & 100 \\
\hline Total & 492 & & 90,8536585 \\
\hline Diagram Pareto Jenis & Cacat pada Assy Tilt
\end{tabular}

Gambar 5. Diagram Pareto Jenis Cacat pada Assy Tilt OWO30

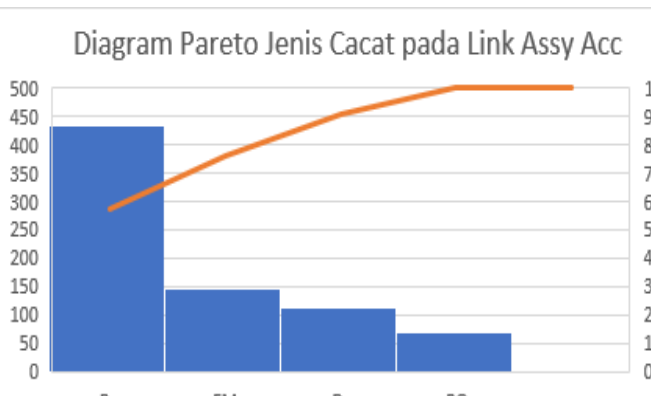

\begin{tabular}{|c|c|c|c|}
$\begin{array}{c}\text { Jenis } \\
\text { Kecacaian }\end{array}$ & $\begin{array}{c}\text { Jumlah } \\
\text { (pcs) }\end{array}$ & $\%$ & $\%$ Kumulatif \\
\hline Bubble & 432 & 56,917 & 56,917 \\
\hline Dirty & 113 & 14,88801 & 71,8050066 \\
\hline $\begin{array}{c}\text { Finger } \\
\text { Mark }\end{array}$ & 145 & 19,10408 & 90,9090909 \\
\hline Peel Off & 69 & 9,090909 & 100 \\
\hline Total & 759 & & \\
\hline
\end{tabular}

Gambar 6. Diagram Pareto Jenis Cacat pada Assy Acc

Diagram Pareto Jenis Cacat pada Bumper OKO50

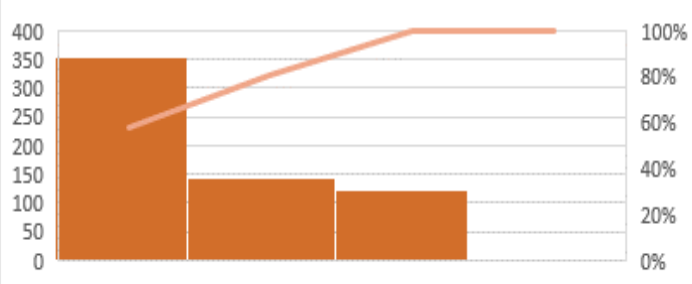

Bu

\begin{tabular}{|c|c|c|c|}
$\begin{array}{c}\text { Jenis } \\
\text { Kecacaion }\end{array}$ & $\begin{array}{c}\text { Jumlah } \\
\text { (pcs) }\end{array}$ & $\%$ & $\%$ Kumulaiff \\
\hline Bubble & 354 & 57,37439 & 57,37439 \\
\hline Scraich & 121 & 19,61102 & 76,9854133 \\
\hline $\begin{array}{c}\text { Finger } \\
\text { Mark }\end{array}$ & 142 & 23,01459 & 100 \\
\hline Total & 617 & & \\
\hline
\end{tabular}

Gambar 7. Diagram Pareto Jenis Cacat pada Bumper OKO50

Tabel 2. Analisa Pareto Rekapan Kecacatan

\begin{tabular}{|c|c|c|c|c|c|c|c|c|c|c|}
\hline \multirow[b]{2}{*}{ Nama Produk } & \multicolumn{10}{|c|}{ Jumlah Berdasarkan Jenis Cacat (pcs) } \\
\hline & Burry & Scratch & $\begin{array}{l}\text { Missing } \\
\text { Bending }\end{array}$ & Dirty & $\begin{array}{c}\text { Finger } \\
\text { Mark }\end{array}$ & $\begin{array}{c}\text { Through } \\
\text { Cut }\end{array}$ & $\begin{array}{l}\text { Over } \\
\text { Hole }\end{array}$ & $\begin{array}{c}\text { Peel } \\
\text { Off }\end{array}$ & Bubble & Total \\
\hline Assy Hood & - & 243 & 298 & 367 & - & - & 121 & - & 65 & \\
\hline Link Assy Acc & 432 & - & - & 113 & 145 & - & - & 69 & - & \\
\hline Hook Engine & 254 & 312 & - & - & 122 & 171 & - & - & - & \\
\hline Bumper OKO50 & 354 & 121 & - & - & 142 & - & - & - & - & \\
\hline Assy Tilt OWO30 & 233 & - & 214 & - & 32 & 13 & - & - & - & \\
\hline Total & 1.273 & 676 & 512 & 480 & 441 & 184 & 121 & 69 & 65 & 3.821 \\
\hline Persentase & $33.31 \%$ & $17.69 \%$ & $13.39 \%$ & $12.56 \%$ & $11.54 \%$ & $4.81 \%$ & $3.16 \%$ & $1.81 \%$ & $1.70 \%$ & $100 \%$ \\
\hline
\end{tabular}


Berdasarkan hasil analisa yang ditunjukkan pada Tabel 2 didapatkan bahwa jumlah jenis cacat terbesar adalah burry dengan presentase 33,31\% kemudian scratch 17,69\%, missing bending 13,39\%, dirty 12,56\%, finger mark $11.54 \%$, through cut $4,81 \%$, over hole $3,16 \%$, peel off $1,81 \%$ dan bubble 1,7\%. Dari hasil perhitungan jumlah cacat kemudian dilakukan analisa sebab-akibat menggunakan Diagram Fishbone untuk masing-masing jenis cacat [10], yang dapat dilihat pada Gambar 8 untuk jenis cacat dirty, Gambar 9 untuk jenis cacat burry, Gambar 10 untuk jenis cacat missing bending, Gambar 11 untuk jenis cacat through cut, Gambar 12 untuk jenis cacat finger mark, Gambar 13 untuk jenis cacat scratch, Gambar 14 untuk jenis cacat peel off, Gambar 15 untuk jenis cacat bubble, dan Gambar 16 untuk jenis cacat over hole.

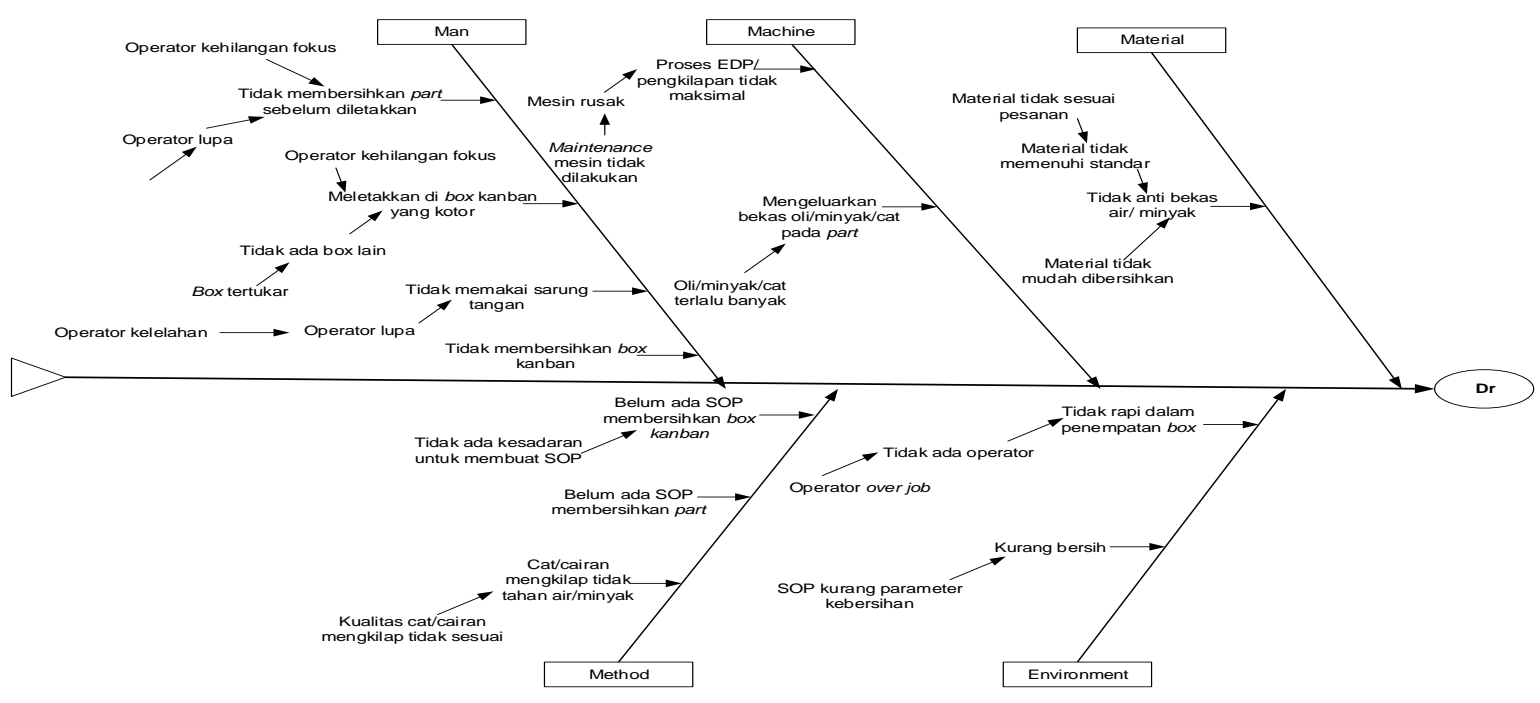

Gambar 8. Fishbone Jenis Cacat Dirty

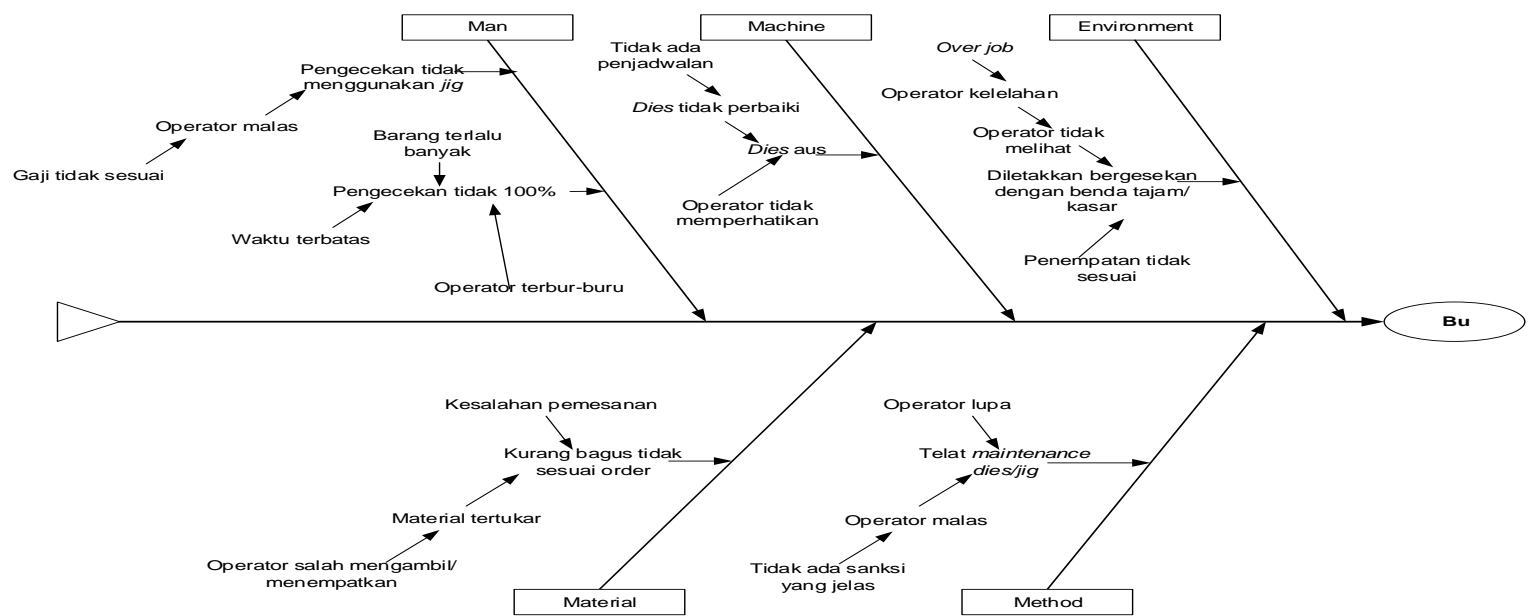

Gambar 9. Fishbone Jenis Cacat Burry 
Analisis Kualitas Produk Drum dan Metal Packaging (Studi Kasus: Plant 1 PT Guna Senaputra Sejahtera) Bintang Bagaskara K., Clara Puspita N., Stephen Alexander, Lithrone Laricha S.

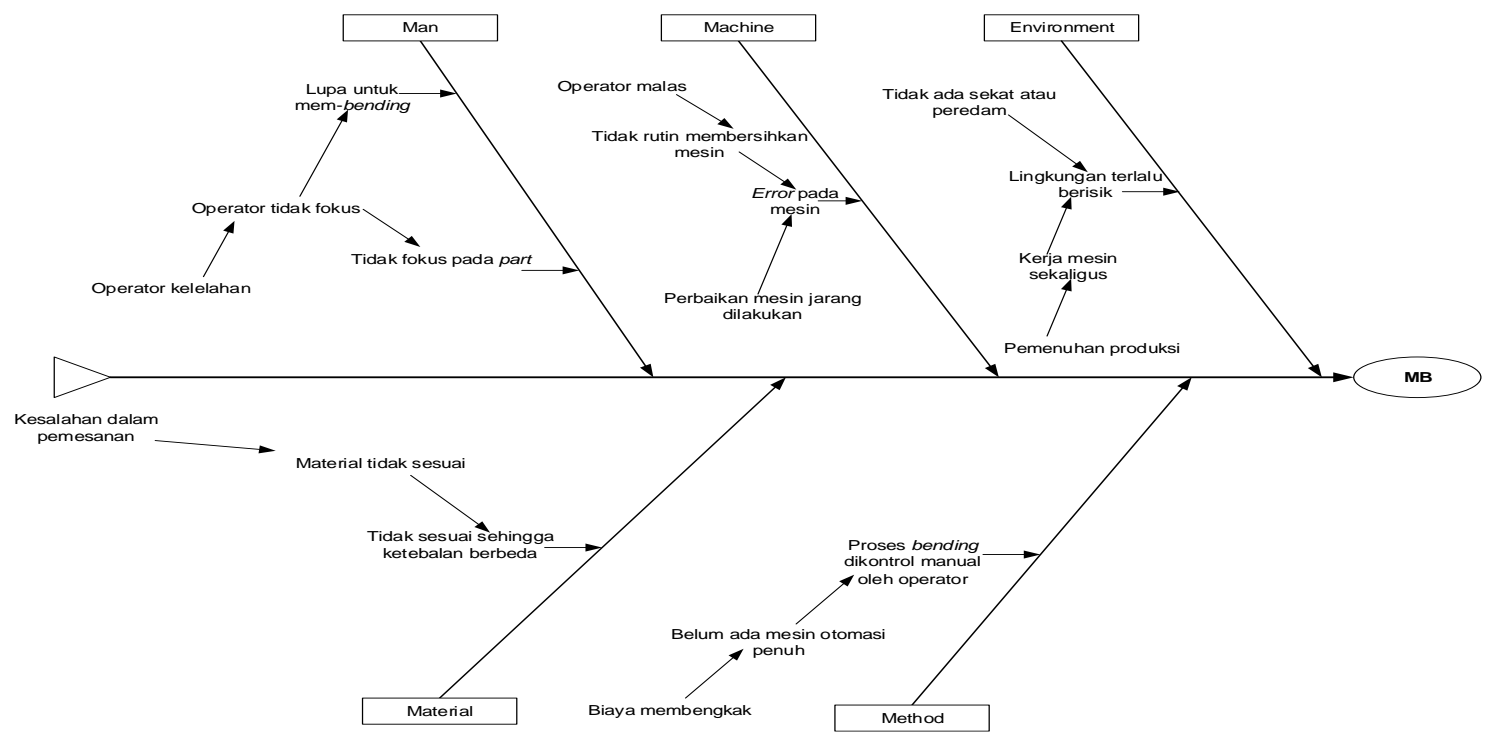

Gambar 10. Fishbone Jenis Cacat Missing Bending

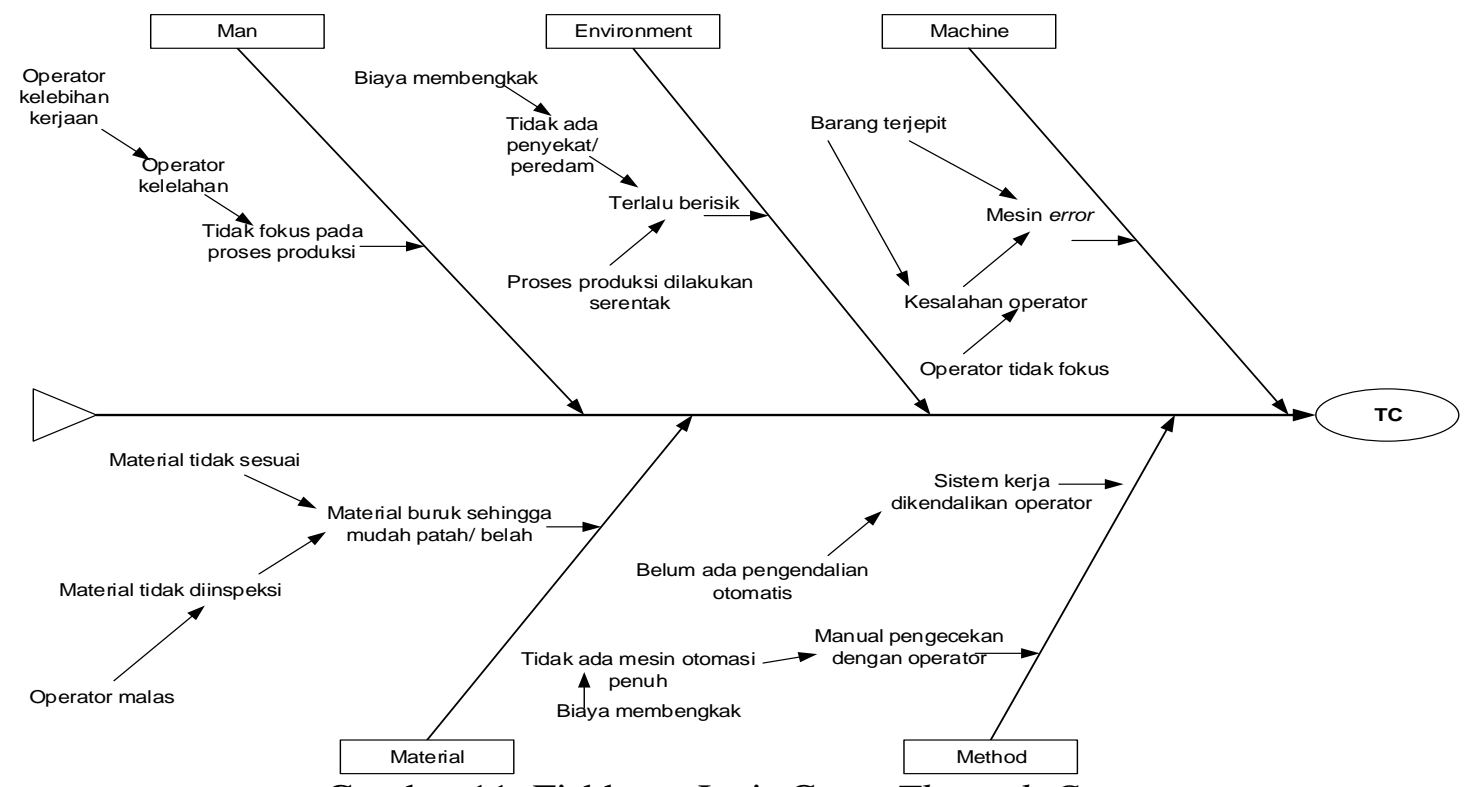

Gambar 11. Fishbone Jenis Cacat Through Cut

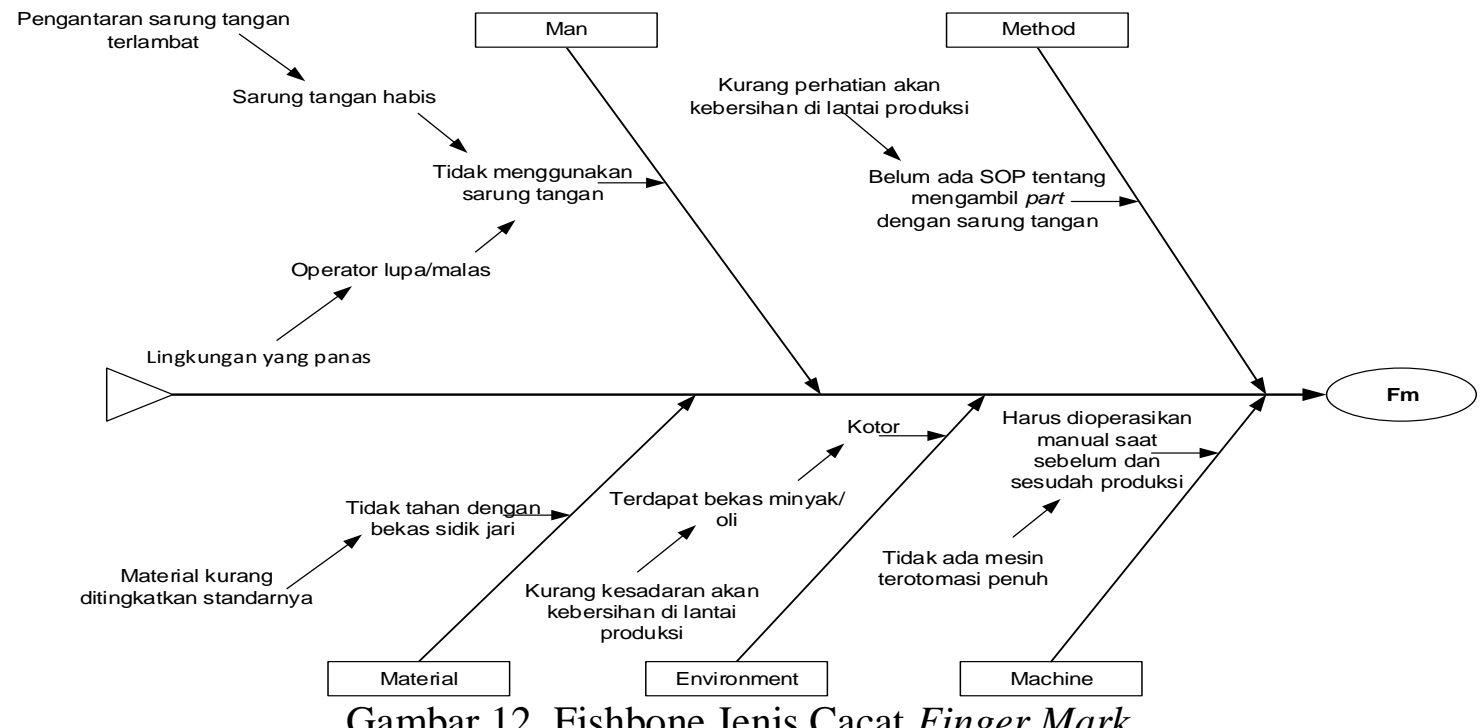

Gambar 12. Fishbone Jenis Cacat Finger Mark 


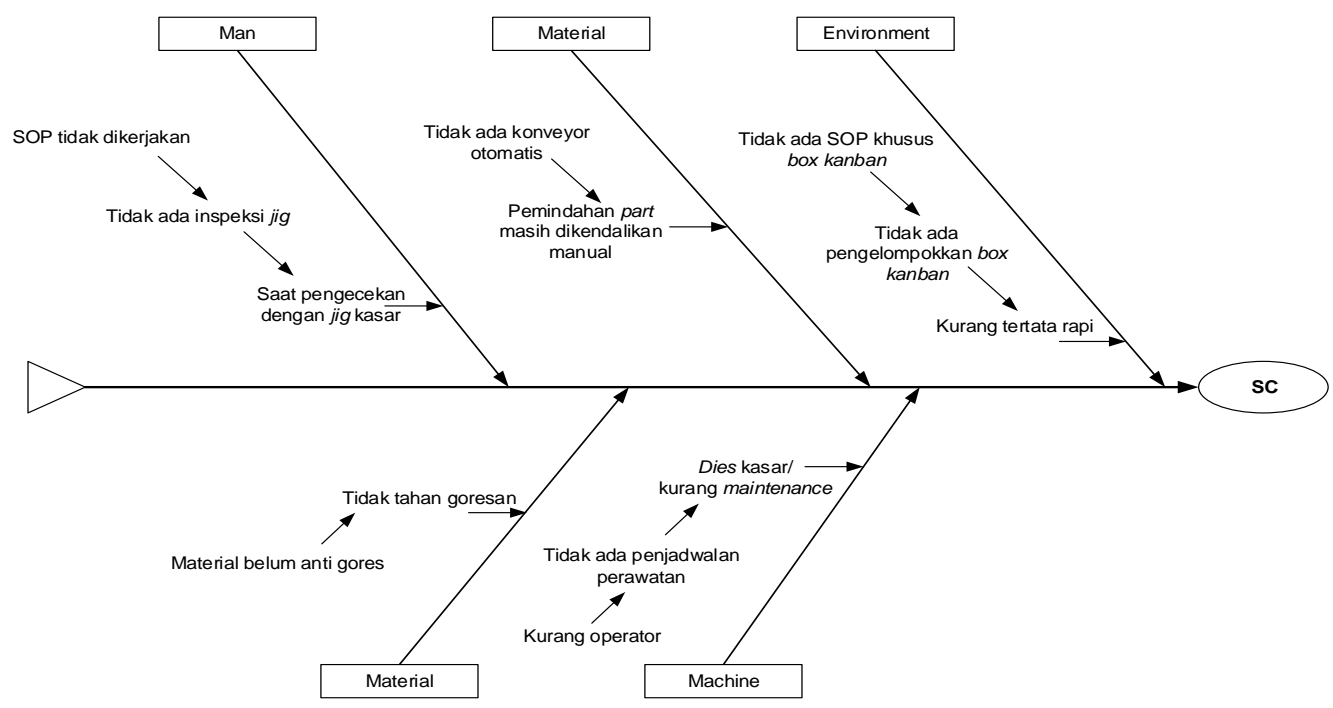

Gambar 13. Fishbone Jenis Cacat Scratch

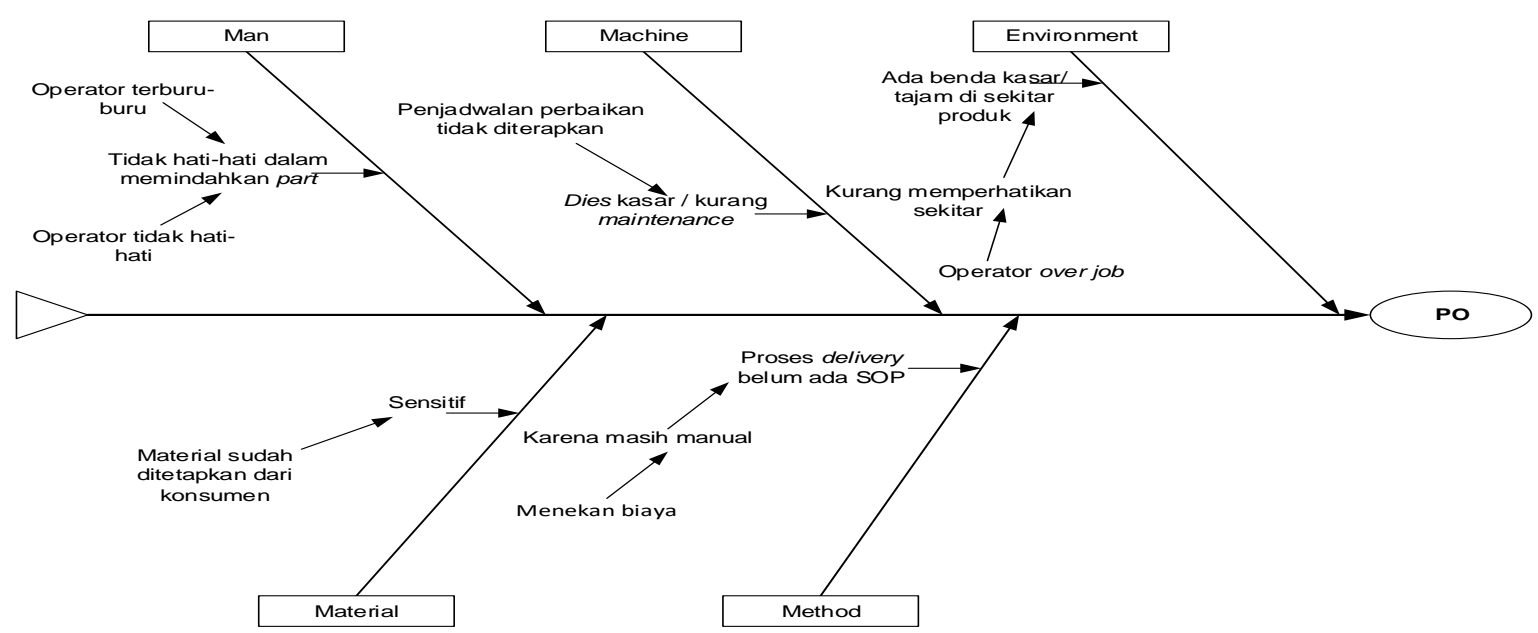

Gambar 14. Fishbone Jenis Cacat Peel Off

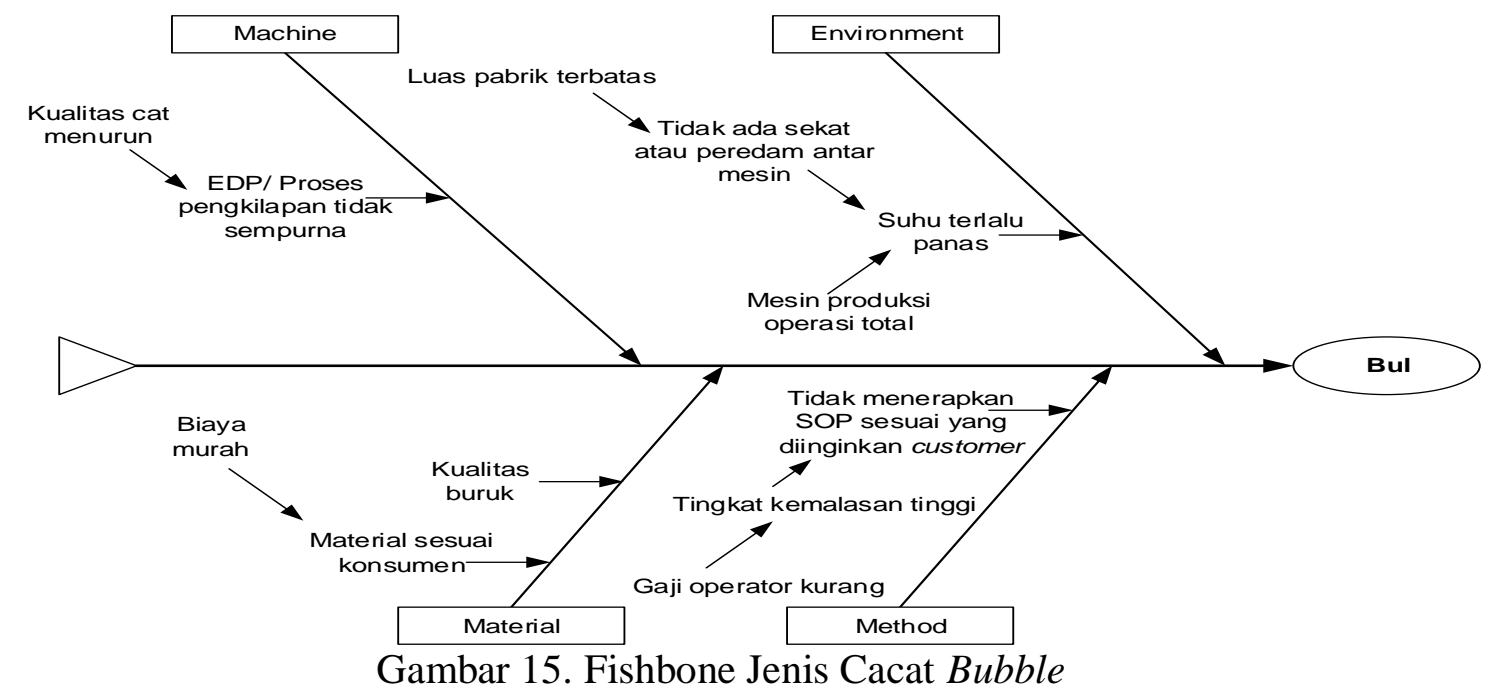

Gambar 15. Fishbone Jenis Cacat Bubble 


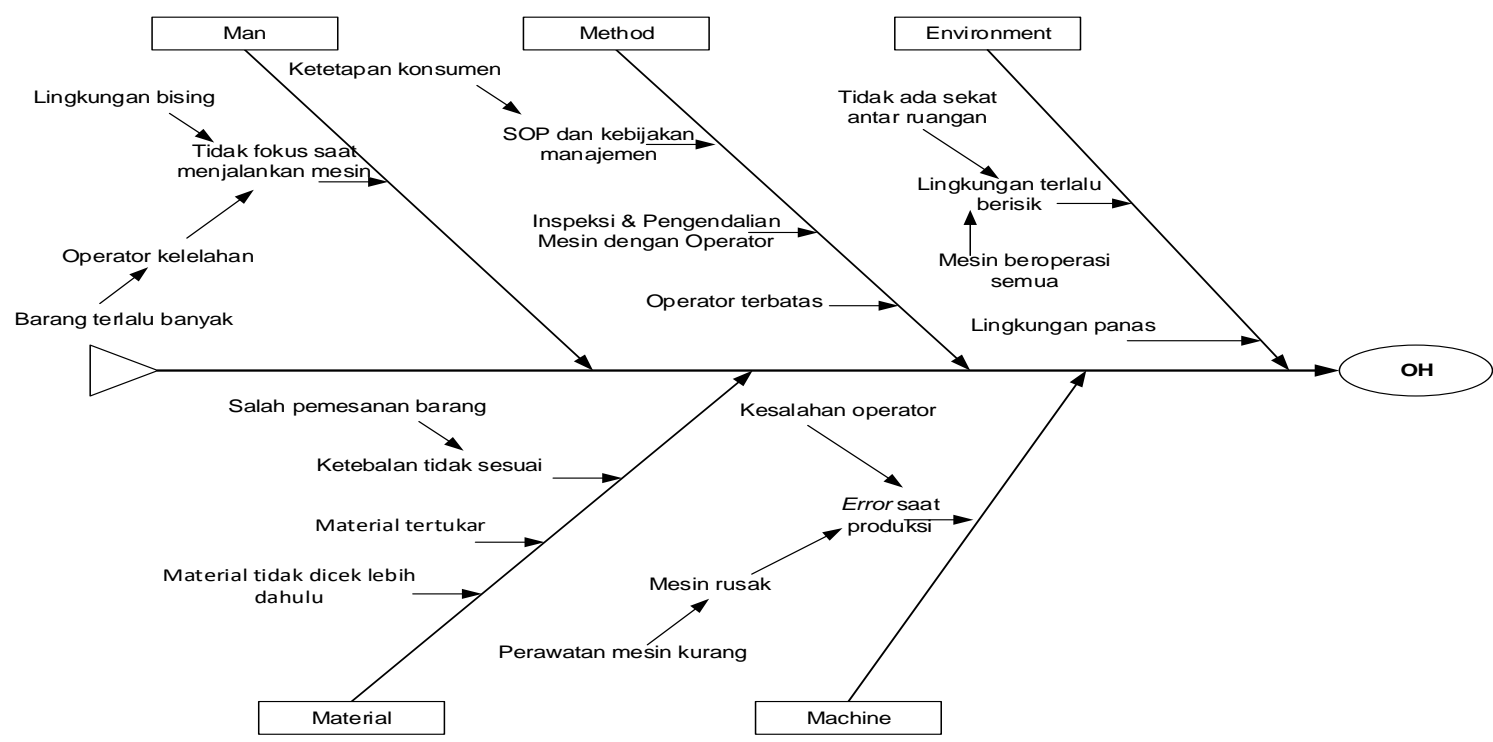

Gambar 16. Fishbone Jenis Cacat Over Hole

Tabel 3. Peta Kontrol Produk Lock Assy Hood

\begin{tabular}{|c|c|c|c|c|c|c|}
\hline $\begin{array}{c}\text { Hari } \\
\text { ke }\end{array}$ & $\begin{array}{c}\text { Jumlah Produk } \\
\text { Cacat }\end{array}$ & $\begin{array}{c}\text { Jumlah } \\
\text { Produksi }\end{array}$ & $\begin{array}{c}\text { Proporsi } \\
\text { Cacat }\end{array}$ & UCL & CL & LCL \\
\hline 1 & 35 & 608 & 0.058 & 0.19 & 0.06 & -0.07 \\
\hline 2 & 34 & 608 & 0.056 & 0.19 & 0.06 & -0.07 \\
\hline 3 & 37 & 608 & 0.061 & 0.19 & 0.06 & -0.07 \\
\hline 4 & 37 & 607 & 0.061 & 0.19 & 0.06 & -0.07 \\
\hline 5 & 37 & 608 & 0.061 & 0.19 & 0.06 & -0.07 \\
\hline 6 & 33 & 609 & 0.054 & 0.19 & 0.06 & -0.07 \\
\hline 7 & 36 & 607 & 0.059 & 0.19 & 0.06 & -0.07 \\
\hline 8 & 38 & 608 & 0.063 & 0.19 & 0.06 & -0.07 \\
\hline 9 & 35 & 606 & 0.058 & 0.19 & 0.06 & -0.07 \\
\hline 10 & 36 & 608 & 0.059 & 0.19 & 0.06 & -0.07 \\
\hline 11 & 36 & 608 & 0.059 & 0.19 & 0.06 & -0.07 \\
\hline 12 & 32 & 608 & 0.053 & 0.19 & 0.06 & -0.07 \\
\hline 13 & 36 & 608 & 0.059 & 0.19 & 0.06 & -0.07 \\
\hline 14 & 38 & 609 & 0.062 & 0.19 & 0.06 & -0.07 \\
\hline 15 & 38 & 608 & 0.063 & 0.19 & 0.06 & -0.07 \\
\hline 16 & 34 & 608 & 0.056 & 0.19 & 0.06 & -0.07 \\
\hline 17 & 35 & 608 & 0.058 & 0.19 & 0.06 & -0.07 \\
\hline 18 & 36 & 608 & 0.059 & 0.19 & 0.06 & -0.07 \\
\hline 19 & 37 & 608 & 0.061 & 0.19 & 0.06 & -0.07 \\
\hline 20 & 36 & 608 & 0.059 & 0.19 & 0.06 & -0.07 \\
\hline 21 & 37 & 607 & 0.061 & 0.19 & 0.06 & -0.07 \\
\hline 22 & 35 & 607 & 0.058 & 0.19 & 0.06 & -0.07 \\
\hline 23 & 38 & 607 & 0.063 & 0.19 & 0.06 & -0.07 \\
\hline 24 & 39 & 608 & 0.064 & 0.19 & 0.06 & -0.07 \\
\hline 25 & 38 & 608 & 0.063 & 0.19 & 0.06 & -0.07 \\
\hline 26 & 39 & 607 & 0.064 & 0.19 & 0.06 & -0.07 \\
\hline 27 & 38 & 607 & 0.063 & 0.19 & 0.06 & -0.07 \\
\hline 28 & 38 & 608 & 0.063 & 0.19 & 0.06 & -0.07 \\
\hline 29 & 38 & 608 & 0.063 & 0.19 & 0.06 & -0.07 \\
\hline 30 & 38 & 608 & 0.063 & 0.19 & 0.06 & -0.07 \\
\hline Total & 1094 & 18233 & 1.800 & & & \\
\hline
\end{tabular}

Dari Tabel 3 menunjukkan bahwa nilai UCL adalah 0.19, nilai CL 0.06 dan nilai LCL -0.07 dan dari Peta Kontrol pada Gambar 17 dapat dilihat bahwa data untuk produk Link Assy Acc masih dalam batas kontrol. Begitu pula untuk Peta Kontrol produk Hook Engine pada Gambar 18, produk Bumper pada Gambar 19, Produk Pipe Tilt pada Gambar 20, dan Produk Lock Assy Hood Pada Gambar 20, hasil pemetaan menunjukkan bahwa data berada dalam batas kontrol. 


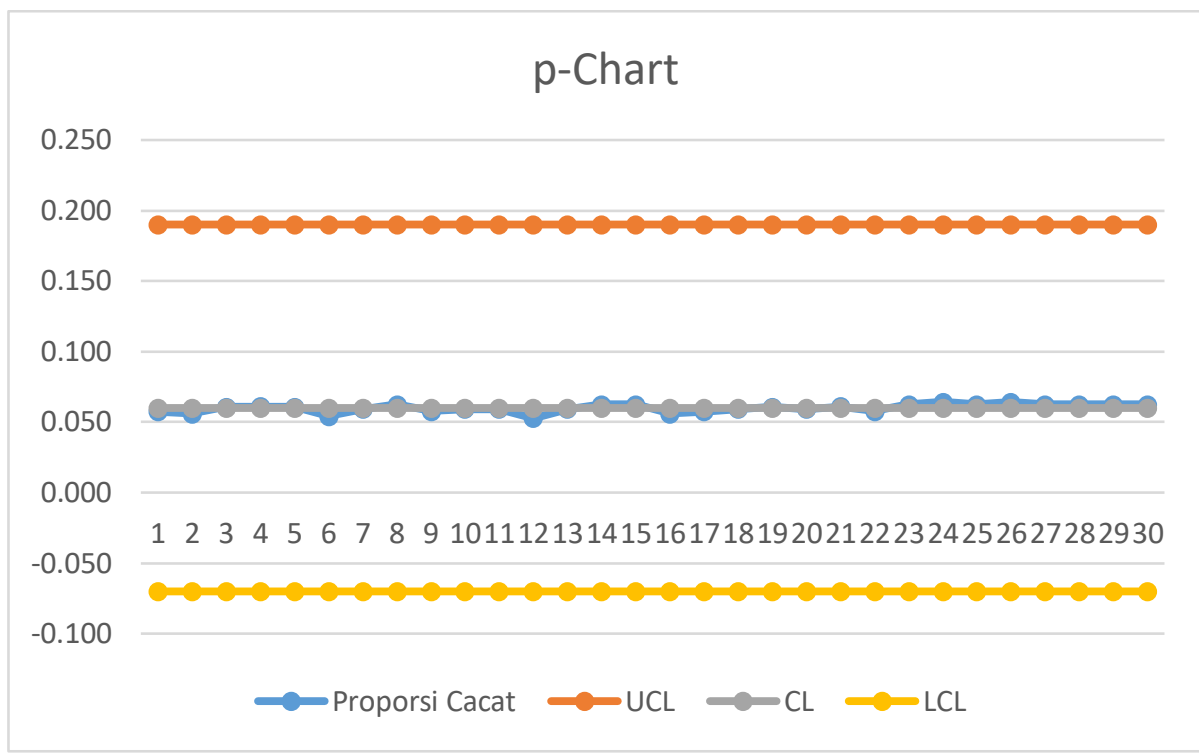

Gambar 17. Peta Kontrol Produk Link Assy Acc

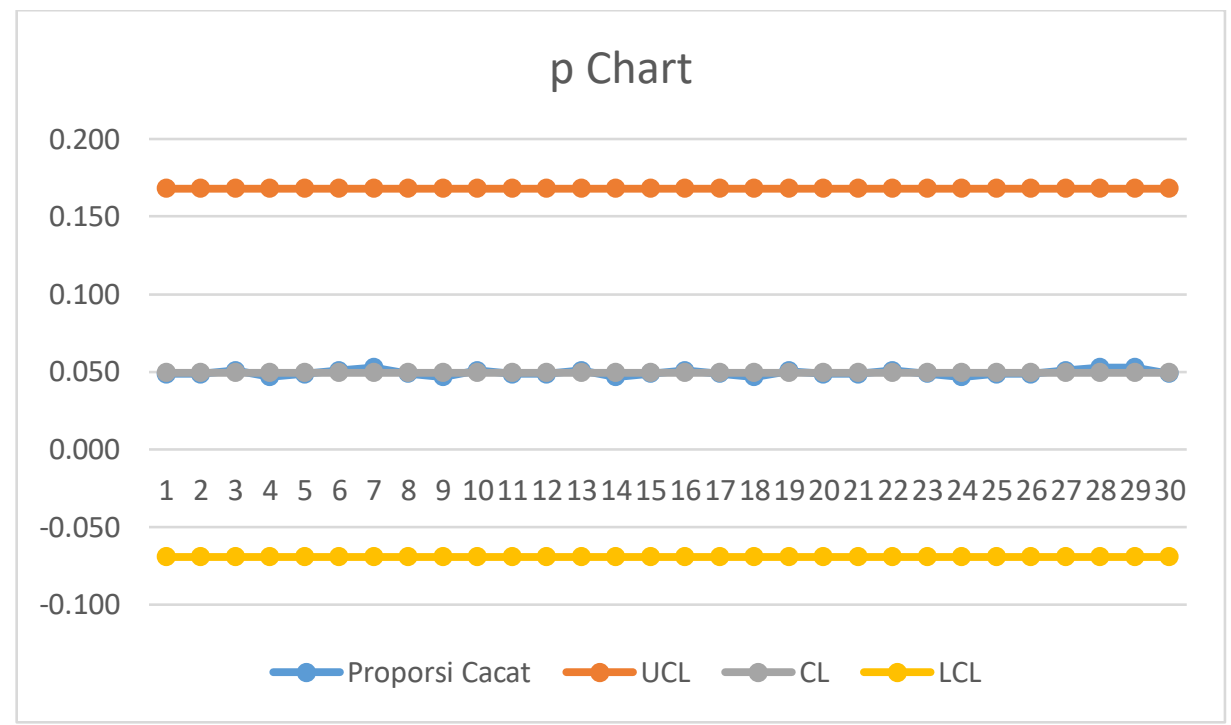

Gambar 18. Peta Kontrol Produk Hook Engine

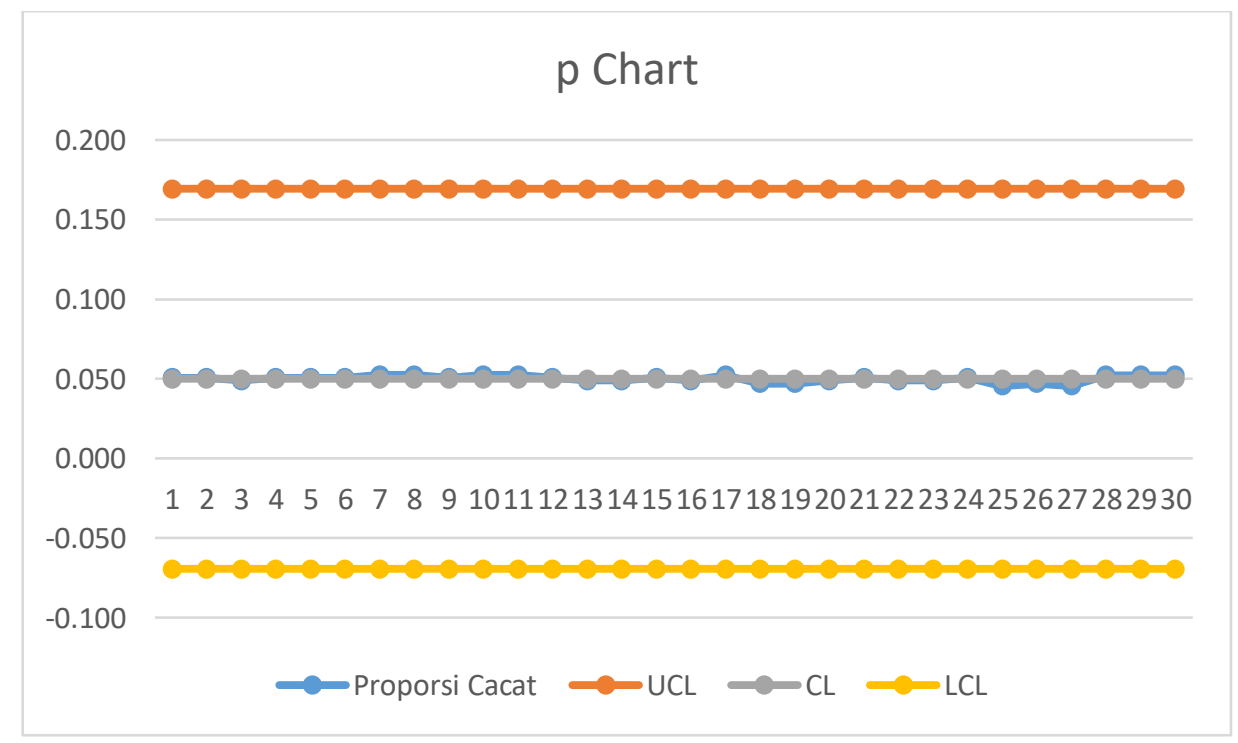

Gambar 19. Peta Kontrol Produk Bumper 


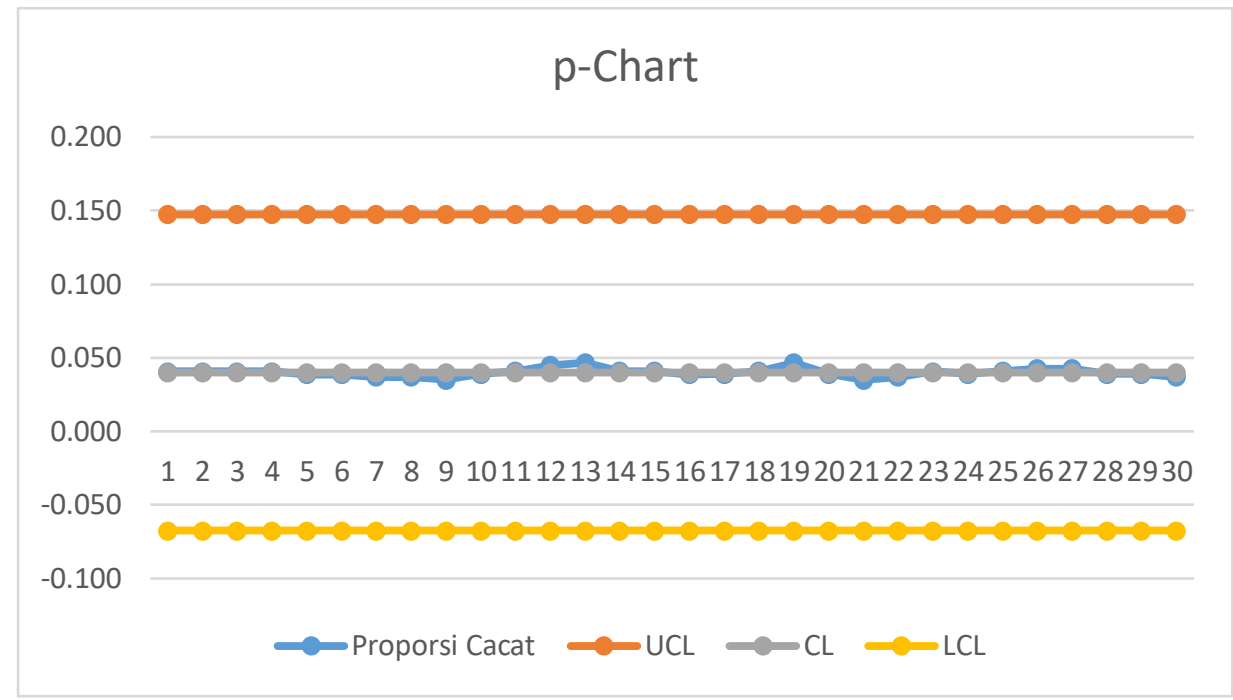

Gambar 20. Peta Kontrol Produk Pipe Tilt

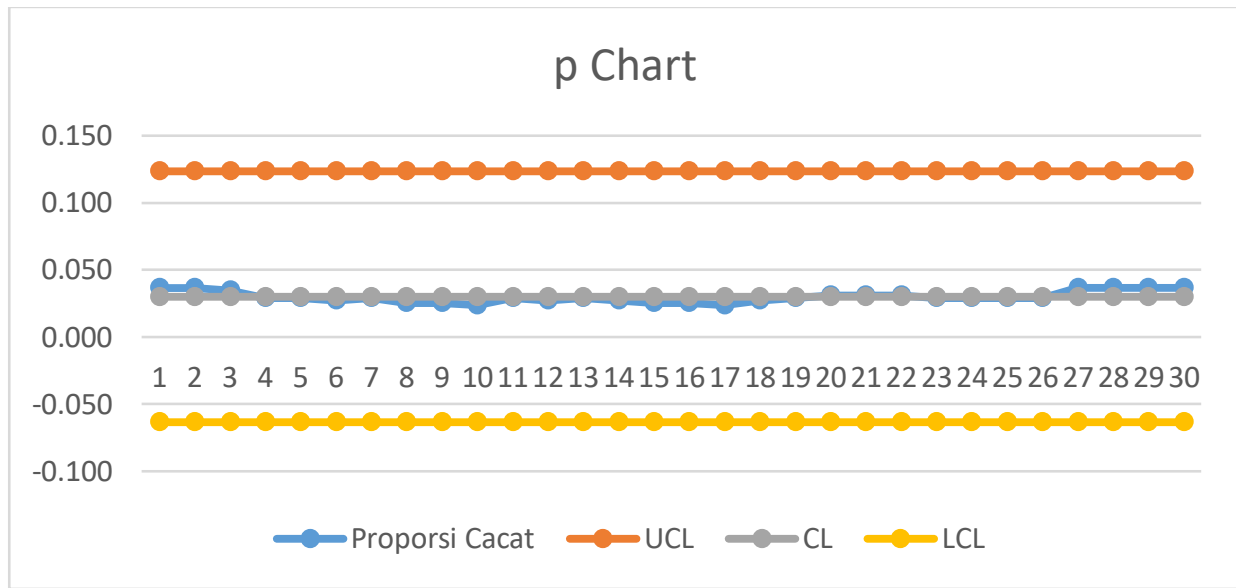

Gambar 21. Peta Kontrol Produk Lock Assy Hood

\section{KESIMPULAN}

Hasil analisis menyimpulkan Produk yang memiliki tingkat kecacatan tinggi adalah Lock Assy Hood (6\%), Link assy Acc (5\%), Hook Engine (5\%), Bumper (4\%), Assy Tilt OWO30 (3\%) sehingga persentase defect masih belum mencapai target yang diharapkan oleh perusahaan (zero defect). Jenis cacat burry, finger mark, scartch, dan dirty merupakan jenis cacat yang dominan pada kelima part tersebut sehingga menyebabkan kerugian baik pada cost, waktu, dan efisiensi proses. Jenis cacat pada kelima produk tersebut didominasi dengan ketidaktelitian operator dan SOP yang tidak dilaksanakan dengan baik/Belum terdapat SOP, lingkungan yang bising juga mempengaruhi kinerja produksi, kurangnya mesin otomasi yang seharusnya tidak lagi dikendalikan oleh operator, dan kurangnya maintenance mesin, jig, dan dies. Terdapat beberapa tindakan yang dapat dilakukan oleh PT Guna Senaputra Sejahtera untuk mengurangi jumlah kecacatan pada produksi kelima part tersebut, yaitu melakukan penjadwalan preventive maintenance berkala pada mesinmesin produksi, jig, dan dies serta pelaksanaan training berkala sehingga operator memiliki kemampuan yang cukup dalam melakukan proses produksi. Juga mensosialisasikan dan membuat SOP dengan jelas serta memberikan anksi apabila melanggar, kemudian memberikan ruangan khusus bagi proses produksi yang bising dan menambahkan pendingin ruangan demi kenyamanan bersama dan meningkatkan produktivitas kinerja operator. 


\section{DAFTAR PUSTAKA}

[1]. Abdullah, Lutfi, 2008. Penerapan Seven Tools dalam Pengendalian Kualitas Produk Kayu Pada PT. Bukit Emas Darma Utama Sumatra Utara. Tugas Akhir. Fakultas Ekonomi Jurusan Manajemen Industri. Universitas Sebelas Maret.

[2]. Ahyari. 1992. Manajemen Produksi. Jilid I. Yogyakarta.

[3]. Gasperz V, 1997, Manajemen Kualitas, PT. Gramedia, Jakarta.

[4]. Gasperz, Vincent. 2005. Total Quality Managament. Jakarta: PT. Gramedia Pustaka Utama.

[5]. Besterfield, Dale H. 1998. Quality Control. New Jersey: Prentice-Hall Inc.

[6]. Feingenbaum, AV. 1992. Kendali Mutu Terpadu. Penerjemah: Kandahjaya H. Terjemahan dari: Total Quality Control. 3 ed. Jakarta: Penerbit Erlangga.

[7]. Grant, E.L. 1995. Pengendalian Mutu Statistik. Jakarta: Erlangga

[8]. Grant,E.L. 1998. Pengendalian Mutu Statistik Jilid 2. Jakarta : Erlangga

[9]. Handoko, T. H. 1984. Dasar-dasar Manajemen Produksi dan Operasi. Yogyakarta: BPFE

[10]. Asmoko, H., 2013, Teknik Ilustrasi Masalah-Fishbone Diagrams, Magelang: BPPK. 